\title{
Xenia Includes Metaxenia
}

\author{
James O. Denney ${ }^{1}$ \\ Department of Pomology University of California, Davis, CA 95616-8683
}

This discussion deals with the terminology and biology of direct, or immediate, pollen effects on seeds and fruits. Such effects are called "xenia" and include differences in the size, shape, color, developmental timing, and chemical composition of seeds and fruits found as a result of fertilization by different pollens. The term "xenia" was originally coined to describe such pollen effects only on maternal plant tissues, that is, on seed coats, pericarp, and attending structures, and these effects were contrasted with those associated with hybridization as expressed in the embryo. Xenia was applied to direct pollen effects on endosperm at a time when this tissue was considered to be purely maternal, that is, before the discovery of double fertilization in the angiosperms. The term continued to be applied to such effects on endosperm after double fertilization was invoked to explain the phenomenon and later was extended to apply to direct pollen effects in embryos in species with exalbuminous seeds. Later still, the term "metaxenia" was mistakenly coined to describe direct pollen effects on maternal plant tissues. This discussion suggests that double fertilization per se does very little to explain xenic effects on the embryo and endosperm. Also, little or no scientific evidence now exists for maintenance of a strict distinction between xenic effects on syngamous tissues ("gamoxenia") and those on maternal tissues ("metaxenia"). Such a distinction appears to be purely hypothetical. Indeed, differences in size, shape, color, developmental timing, and chemical composition may be simultaneously found in embryo, endosperm, and maternal tissues in some species. The term "xenia," therefore, covers all direct pollen effects in seeds and fruits, whether discerned in embryo, endosperm, or maternal tissues, in the period from fertilization to germination. Whereas there has been adequate description of xenic effects, explanation of the effects by way of focused scientific research has been lacking in most species, and the

Received for publication 31 Oct. 1991. Accepted for publication 2 Jan. 1992. I thank George Martin, Vito Polito, Thomas Gradziel, Frank Dennis, and James Soule for reviewing the manuscript and for their valuable suggestionsfor its improvement. Special thanks go to Edward Coe, John Yoder, and Ivan Buddenhagen for helping to orient me in corn genetics and to Gabriele Ludwig and Henrik Stotz for their translations from the German of the works of Focke, Nawaschin, and Correns. The cost of publishing this paper was defrayed in part by the payment of page charges. Under postal regulations, this paper therefore must be hereby marked advertisement solely to indicate this fact.

${ }^{1}$ Research Assistant and Graduate Student. biology of xenia remains obscure. Advances in corn (Zea mays L.) genetics, notably research on parental imprinting, paramutation, and transposable genetic elements, as discussed below, may suggest useful approaches to understanding the phenomenon in other species. Also, xenic size effects previously documented in date fruit (Phoenix dactylifera L.) should be investigated using modem techniques of phytohormone analysis. Xenia has applications not only in genetic and physiological research but also in plant breeding and crop production.

That pollen from different sources affects readily discernible characteristics of seeds and fruits in the period immediately following fertilization has been noted for well over a century. Such immediate or direct effects are termed "xenia" and have been described in many species (Focke, 1881). These effects on tissues of purely maternal origin, rather than on parts resulting from syngamy, have also been termed "metaxenia" (Swingle, 1928). The present discussion springs from the fact that there is widespread confusion about the meaning of these two terms and, more importantly, whether they can be distinguished, and if so, how. Understanding the history of these terms will aid in this attempt to clarify their use and to elucidate the underlying mechanisms involved in the phenomenon or phenomena described. The basic premise to be outlined here is that the term "metaxenia" was created superflu-

Table 1. Various definitions of xenia and metaxenia.

\begin{tabular}{|c|c|c|}
\hline Source & Xenia & Metaxenia \\
\hline Kirkpatrick, 1987 & $\begin{array}{l}\text { n. (bot.) Direct influence of pollen on endo- } \\
\text { sperm (explained by double fertilization) or } \\
\text { on mother-plant of embryo. }\end{array}$ & --- \\
\hline Morris, 1976 & $\begin{array}{l}\text { n. Botany. Effect on a hybrid plant produced by } \\
\text { transfer of pollen from one strain to seed of a } \\
\text { different strain. }\end{array}$ & $\cdots$ \\
\hline Neufeldt, 1988 & $\begin{array}{l}\text { n. (Bot.) Immediate influence of pollen from } \\
\text { one strain of a plant on endosperm of another } \\
\text { strain, resulting in hybrid characters in form, } \\
\text { color, etc. of resulting growth, as in colors of } \\
\text { corn grains. }\end{array}$ & --- \\
\hline Reiger et al., 1976 & $\begin{array}{l}\text { Seeds whose hybrid nature is recognizable by } \\
\text { particular phenotypic characters (color, shape, } \\
\text { size, etc.) owing to direct influences exerted } \\
\text { by genotype of pollen on embryo or on ma- } \\
\text { ternal tissue (endosperm) of fruit. }\end{array}$ & $\rightarrow$ xenia \\
\hline Soule, 1985 & $\begin{array}{l}\text { Immediate effect of pollen on endosperm as a } \\
\text { result of double fertilization (union of sperm } \\
\text { with egg and two polar nuclei) in seed parent. }\end{array}$ & $\begin{array}{l}\text { Direct effect of pollen on parts } \\
\text { of seed and fruit outside em- } \\
\text { bryo sac. }\end{array}$ \\
\hline Westwood, 1989 & $\begin{array}{l}\text { Physiological effect of foreign pollen on ma- } \\
\text { ternal fruit tissue (this term formerly was ap- } \\
\text { plied to pollen effects on embryo and } \\
\text { endosperm). }\end{array}$ & $\begin{array}{l}\text { Physiological effects of foreign } \\
\text { pollen on the maternal tissue } \\
\text { of fruit. }\end{array}$ \\
\hline Winburne, 1962 & $\begin{array}{l}\text { Immediate effect of pollen on endosperm due to } \\
\text { phenomenon of double fertilization that may } \\
\text { allow male parent to affect appearance of seed. }\end{array}$ & $\begin{array}{l}\text { Direct effect of pollen on parts } \\
\text { of seed and fruit that lie out- } \\
\text { side embryo and endosperm. }\end{array}$ \\
\hline
\end{tabular}

ously and erroneously to cover phenomena already designated by the term "xenia." It will become clear, however, that, as Sedgley and Griffin (1989) have stated, any speculations on xenia and metaxenia at present are purely "academic . . . in view of the genof xenial and metaxenial action." Nevertheless, this contribution may spur others to take up study of the mechanisms involved in this widespread but poorly understood phenombeing "of the highest theoretical importance."

\section{ETYMOLOGY，DEFINITION，AND CONFUSION}

Both xenia and metaxenia are based upon a Greek root, xenos, meaning "a foreigner or guest." In Greek, the word xenia is an abstract noun meaning "hospitality." The prefix meta- means "beyond, behind, or after," or it can indicate a change or transformation, as in "metamorphosis."

There is considerable confusion concerning definitions of xenia and metaxenia (Table 1). Many of the definitions directly conflict with each other; others overlap, but not precisely. Kirkpatrick (1987) says xenia applies to pollen effects on maternal tissue and endosperm, but for Morris (1976) the term applies to seeds, which of course may involve both syngamous and maternal tissue. Morris' definition also betrays an ignorance of the eral lack of knowledge regarding the mode enon, one described by Darwin (1896) as 
specifics of plant sexual reproduction. Neufeldt (1988) limits use of the term "xenia" to effects on endosperm. Reiger et al. (1976) include the embryo along with the endosperm and maternal tissue in their definition. These authors also seem to suggest that endosperm is maternal tissue. Why this is the case will become clear later. Soule (1985) limits xenia to endosperm, and, like Kirkpatrick, he invokes the double fertilization of the angiosperms as explanation. Westwood (1989) has identical definitions for xenia and metaxenia, but his definition of xenia specifically excludes embryo and endosperm. Winburne (1962) says that only endosperm shows the direct effect of pollen in xenia.

Definitions for metaxenia are fewer but more unified. Reiger et al. (1976) refer to xenia for a definition of metaxenia. Westwood (1989) also indicates that the terms are equivalent. Soule, Westwood, and Winburne direct attention to maternal plant tissue in their definitions of metaxenia, but their methods of expressing this are varied and somewhat confusing. Even if we ignore the lexicographers' uncertainty on things botanical, we are, as plant biologists, left with many questions. In the definitions for xenia, maternal tissue is mentioned three times, endosperm five times, and embryo twice. Metaxenia counts three mentions of maternal tissue, twice by making reference to exclusion of embryo or endosperm. So, then, does xenia apply to pollen effects on endosperm alone, on embryo and endosperm, or on embryo, endosperm, and maternal plant tissues in the fruit as well? Are xenia and metaxenia different? If so, how? Is there a clear boundary between these phenomena? What are the underlying mechanisms for direct pollen effects? In the process of this discussion, I will offer some answers to these questions, largely because they deal with questions of terminology and the history associated with the linguistic process of term coinage and definition. Other questions have only partial answers, and yet others must await focused scientific research before our curiosity is satisfied. I will address the historical and linguistic questions first.

\section{XENIA}

The term xenia was coined by Wilhelm Focke (1881). In his writing on what he called "plant mixtures," he states:

The opinion is widespread that the effects of a hybrid fertilization show up in general in the new individual derived from the sexual union but that every so often under conditions that are not well understood the effects can be seen already in the fruit, which in higher plants is a part of the mother plant. Hybridization and the changes in appearance of a plant pollinated with foreign pollen are two separate phenomena that are not connected. Therefore, I suggest that such variations in the normal appearance or in coloration of some part of a plant through the influence of foreign pollen should be called "xenia"-somewhat like a gift from the pollendonating plant to the pollen-receiving one.

It is not clear why Focke chose this specific term. How does the action of foreign pollen suggest hospitality? In many cultures it is considered good manners for a guest to bring a gift, but such expectations are hardly a part of hospitality, which is an attitude displayed by a host rather than by a guest. Focke may instead have been influenced by the word xenium (plural xenia), which is a gift offered to a person of high rank.

After coining this term, Focke goes on to describe two different forms of xenia, "xenoplasms," which are changes in fruit form and which can be assumed to include effects on size as well as on shape, and "xenochromes," which are changes in fruit color. Color, shape, and size of fruits and fruit parts remain the crux of the discernible characteristics affected in this process. Over the years, however, investigators have added to the list of characters, notably sweetness or sugar content and time of maturity. Characteristics of internal chemical composition of fruits and seeds other than sugars, such as oils, amino acids, proteins and tannins, have been added to the list of xenic effects with time and as analytical techniques have improved.

Darwin (1896) never used the term "xenia," but he too took note of this plant phenomenon when he states:

...the action of foreign pollen on the mother-plant...is in itself a remarkable and apparently anomalous circumstance. That it is remarkable under a physiological point of view is clear, for the male element not only affects, in accordance with its proper function, the germ, but at the same time various parts of the mother-plant, in the same manner as it affects the same part in the seminal offspring from the same two parents. We thus learn that an ovule is not indispensable for the reception of the influence of the male element...I may premise that with plants the ovarium and the coats of the ovules are obviously parts of the female, and it could not have been anticipated that they would have been affected by the pollen of a foreign variety or species, although the development of the embryo, inside the embryonic sack [sic] inside the ovule and ovarium, of course, depends on the male element.

Table 2. Quantitative xenic effects, including size.

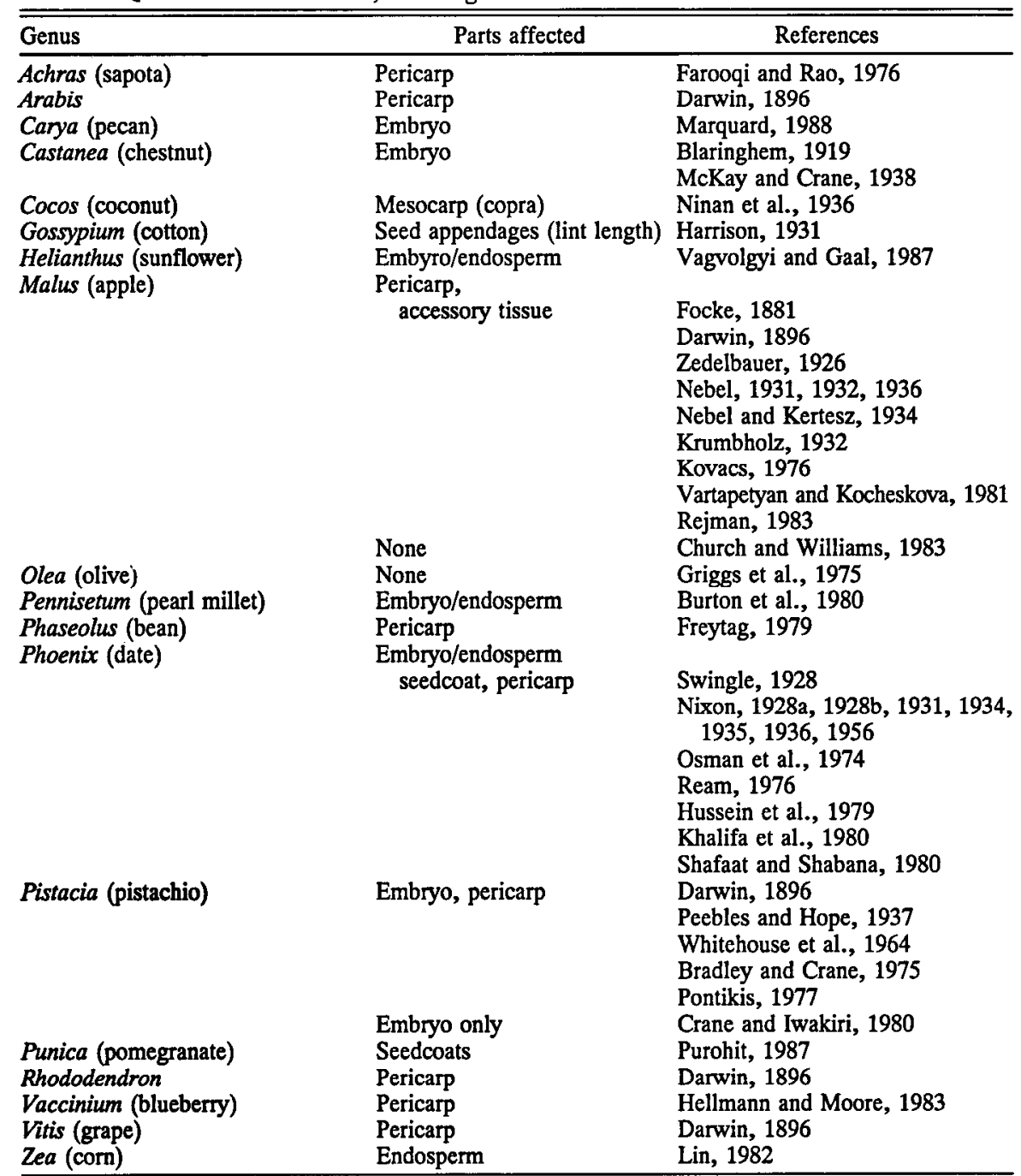


Both Focke and Darwin provide numerous examples based, as Darwin says, "on the authority of several excellent observers." It is clear from the examples provided that the phenomenon described is not one limited to endosperm, though corn figures prominently among the examples. Since that time, numerous investigators-excellent observers all-have added to the list of examples (Tables 2, 3, and 4).

Although much has been done in terms of the documentation and description of xenic effects, little focused work on the mechanisms underlying the observations has been undertaken in most species. One rather basic, but nevertheless monumentally important, mechanism was discovered during the time of Darwin and Focke: This was the discovery of double fertilization in the angiosperms, first described by Strasburger (1878), then confirmed by Nawaschin (1898). The fertilization of the endosperm was immediately seized upon by Correns $(1899,1901)$, the scientist responsible for the rediscovery of the work of Mendel, and by deVries (1899) as explanation for xenia in corn. Xenia has played a central role in corn genetics since that time, although these origins are often neglected in modern writings.

Nevertheless, the discovery of double fertilization created a problem in the definition of xenia, one that seems to have gone unnoticed. Previously, endosperm had been considered to be derived wholly from motherplant tissue. As such, pollen effects on endosperm fit under the definition for xenia given by Focke (1881). Recall that Focke distinguished between two types of pollen effects, hybridization and xenia. With the discovery of the fertilization of the polar nuclei by the second generative nucleus of the pollen, endosperm effects should have been subsumed under hybridization. Instead, such endosperm effects continued to be called xenia. Double fertilization "explained" xenia in corn, but by Focke's definition, it was no longer xenia. Nevertheless, the term continued to be applied to the example of corn, and it is here that the confusion in terms truly began.

At this point, then, the term "xenia" applied to direct pollen effects on maternal tissues and on endosperm. Because of the famous case of "xenia" in corn and its association with double fertilization, it was perhaps only a matter of time before the term was applied to direct pollen effects in the other seed part created by double fertilization, the embryo. The first reference to embryoxenia appeared in an article on chestnut (Castanea sativa Mill.) (Blaringhem, 1919). In chestnut, as with other exalbuminous seeds, the endosperm disappears early in fruit development and the cotyledons become the organs for storage of food reserves. By this point, the term "xenia" had come full circle: the original intent was to distinguish the pollen effects inherent in the hybridization expressed in the embryo, Focke's "new individual derived from the sexual union," from pollen effects somehow expressed in maternal tissues, Focke's "gift from the pollen-
Table 3. Qualitative xenic effects: Color.

\begin{tabular}{|c|c|c|}
\hline Genus & Parts affected & References \\
\hline $\begin{array}{l}\text { Achras (sapota) } \\
\text { Calceolaria } \\
\text { Castanea (chestnut) } \\
\text { Citrus }\end{array}$ & $\begin{array}{l}\text { Pericarp } \\
\text { Flower } \\
\text { Embryo } \\
\text { Pericarp }\end{array}$ & $\begin{array}{l}\text { Farooqi and Rao, } 1976 \\
\text { Focke, } 1881 \\
\text { McKay and Crane, } 1938 \\
\text { Focke, } 1881 \\
\text { Darwin, } 1896 \\
\text { Swingle, } 1928\end{array}$ \\
\hline $\begin{array}{l}\text { Diospyros (persimmon) } \\
\text { Fuchsia } \\
\text { Malus (apple) }\end{array}$ & $\begin{array}{l}\text { Pericarp } \\
\text { Flower } \\
\text { Pericarp, } \\
\quad \text { accessory tissue }\end{array}$ & $\begin{array}{l}\text { Noguchi, } 1935 \\
\text { Focke, } 1881 \\
\text { Focke, } 1881 \\
\text { Darwin, } 1896 \\
\text { Nebel, } 1931 \\
\text { Mackowiak, } 1974 \\
\text { Rejman, } 1983\end{array}$ \\
\hline $\begin{array}{l}\text { Matthiola (stock) } \\
\text { Phoenix (date) }\end{array}$ & $\begin{array}{l}\text { None } \\
\text { Seedcoat } \\
\text { Seedcoats, } \\
\text { pericarp }\end{array}$ & $\begin{array}{l}\text { Church and Williams, } 1983 \\
\text { Darwin, } 1896 \\
\text { Swingle, } 1928 \\
\text { Nixon, 1928, } 1936 \\
\text { Osman et al., } 1974\end{array}$ \\
\hline Pisum (pea) & Seedcoat & $\begin{array}{l}\text { Focke, } 1881 \\
\text { Darwin, } 1896\end{array}$ \\
\hline $\begin{array}{l}\text { Pyrus (pear) } \\
\text { Raphanus (radish) } \\
\text { Rubus } \\
\text { Vitis (grape) }\end{array}$ & $\begin{array}{l}\text { Pericarp, accessory tissue } \\
\text { Pericarp } \\
\text { Flower } \\
\text { Pericarp }\end{array}$ & $\begin{array}{l}\text { Tufts and Hansen, } 1933 \\
\text { Focke, } 1881 \\
\text { Focke, } 1881 \\
\text { Focke, } 1881 \\
\text { Darwin, } 1896\end{array}$ \\
\hline Zea (corn) & Endosperm & $\begin{array}{l}\text { Focke, } 1881 \\
\text { Darwin, } 1896 \\
\text { Correns, } 1899 \\
\text { deVries, } 1899 \\
\text { McClintock, 1950 } \\
\text { Wright and Neuffer, } 1989\end{array}$ \\
\hline
\end{tabular}

Table 4. Qualitative xenic effects: Characteristics other than color.

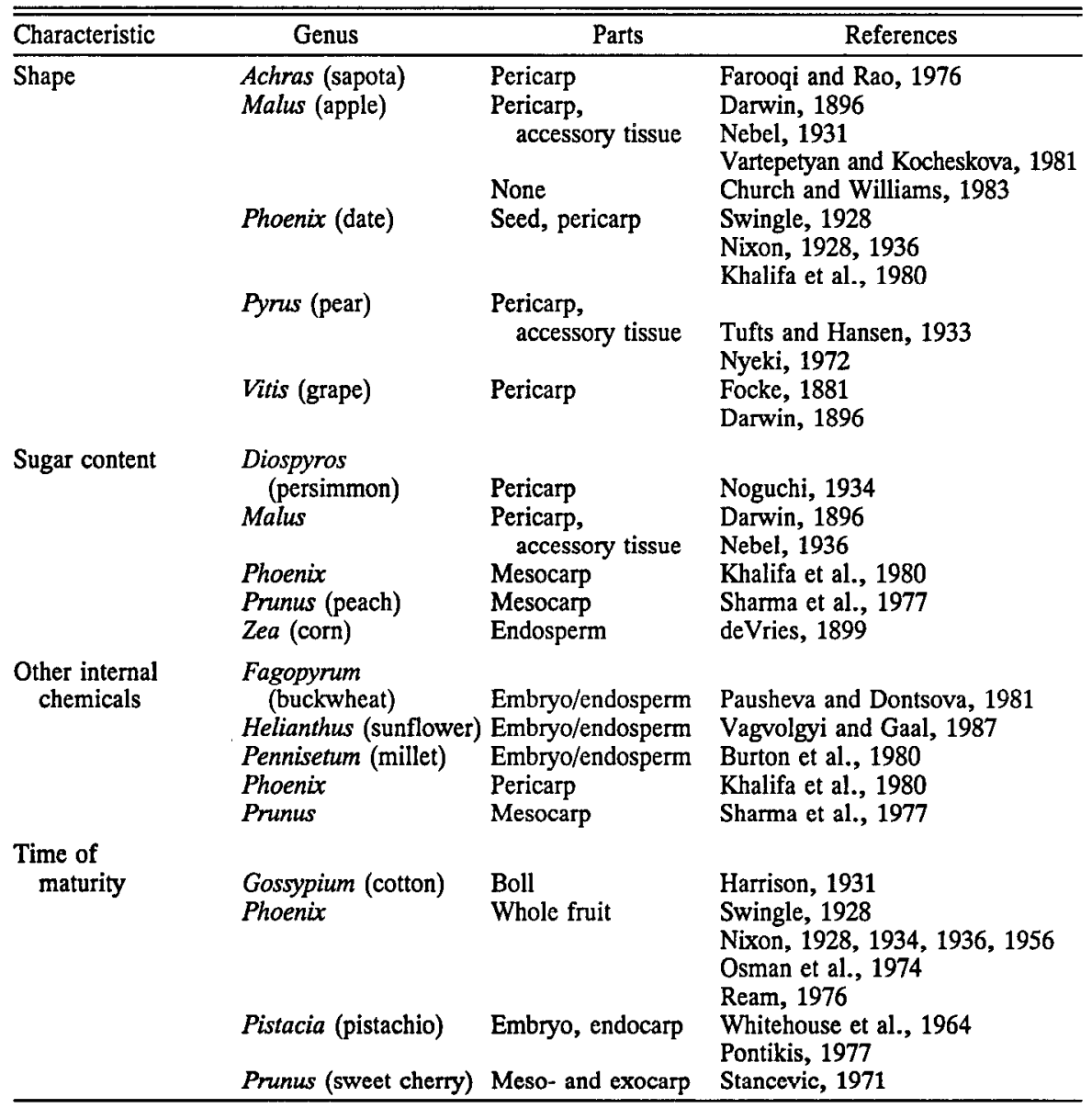


donating plant to the pollen-receiving one." Now, however, the crux of the matter seemed to be any pollen effects that were seen immediately in seeds and fruits.

\section{METAXENIA}

The next episode in the story unfolded as plant physiology began to assert itself as a discipline in the third decade of the 20th century. As part of a report on plant physiology at the Ithaca Conference of Plant Science, Thone (1926) spoke about a presentation by W.T. Swingle, a horticulturist best known for his classification of species of Citrus and related genera:

... experiments ... have demonstrated very strikingly the influence of pollen, not only on the size, shape, and character of the seed, but also on the size, shape and character of the fruit of the date palm, and what is more striking, on the time of ripening. It seems impossible to reconcile the observed effects of different kinds of date pollen with the existing theory of the influence of the male gamete. The double fertilization of the egg cell and the endosperm mother cell [sic] explains satisfactorily the influence of the pollen on the date seed itself, this being a form of xenia. However, the striking influence on...the fruit cannot be explained by the theory of xenia, but apparently necessitates the recognition of influences in the plant both analogous to those exerted by ductless glands in the animal body. The simplest hypothesis is that the embryo or the endosperm of the date seed, or both together, constitute a ductless gland apparatus that affects, by secreting hormones, the whole development of the date fruit, including tissues belonging morphologically to the mother plants, and especially to the thickened ovary walls which constitute the edible portion of the date fruit.

Similar effects have been noted also in citrus fruits. The phenomenon is called meta-xenia [sic].

Swingle's acuity in formulating a scientific hypothesis to explain his observations is marred by problems in scholarship and terminology. Because he had done work on corn (Kellerman and Swingle, 1888), Swingle (1928) was familiar with the explanation given for xenia in that species:

I well remember many years ago securing striking proof of the immediate action of pollen on the character, shape, size, and color of maize kernels and I well remember how baffling this result was and how impossible it proved to understand or even discuss intelligently this immediate effect of pollen on maize, until the discovery of double fertilization in the higher plants lead [sic] to the almost immediate recognition of the nature of xenia in maize and other plants. The double fertiliza- tion of the higher plants was discovered by S. Nawaschin in 1898, and next year [sic] deVries and Correns showed clearly that xenia in maize could be explained by the fertilization of the endosperm by the second generative nucleus of the pollen tube. From this time on xenia became a clearly understood, completely proved phenomenon to be studied like any other phenomena occurring in plants.

Although Correns (1899) cites Focke (1881), Swingle apparently neglected to consult all of the literature, and as a result he did not know that the term xenia applied to pollen effects on parts of the mother plant and that only later did it begin to be applied-somewhat erroneously, as we have seen-to effects on the endosperm. Swingle's choice of the term "metaxenia" seems to have been questioned from the beginning (Schaffner, 1928), but without apparent effect.

\section{CLARIFICATION}

The confusion between "xenia" and "metaxenia" persists, as evidenced by the kinds of definitions available for the two words. However, at least the disparities in the definitions can now be understood. Some lexicographers have relied on Focke's (1881) original formulation, whereas others have relied on Swingle's (1928) misunderstanding. To recap, Focke used "xenia" to describe direct pollen effects on maternal plant tissue; Swingle used "xenia" to describe direct pollen effects on (embryo and) endosperm and "metaxenia" for effects on maternal-plant tissue. To this day, for scientists who study corn, "xenia" applies to pollen effects in endosperm alone, and this prejudice is reflected in several of the definitions.

Pollen effects on maternal-plant tissues of fruits are perhaps more difficult to explain than those effects on parts produced by syngamy, but it is not clear whether this fact alone may justify keeping a separate term, "metaxenia." Likewise, it is not clear how well double fertilization really explains xenia. It is also doubtful that xenia is, in Swingle's words, "a clearly understood, completely proved phenomenon." Xenia surely exists as a phenomenon, but it is only somewhat better understood today than it was at the time Swingle wrote. At most, double fertilization provides a basis for understanding xenic effects in embryo and endosperm. Yet, even if we accept Swingle's formulation, the question of whether xenia and metaxenia are different phenomena is still open to debate. For example, Swingle invokes the action of the embryo and endosperm to explain metaxenia. If the embryo secretes hormones affecting maternal tissue, how can the endosperm and the embryo itself not be affected by these same hormones? Indeed, pollen effects on size are seen in both the seed and the carpel tissue in date (Nixon, 1928; Swingle, 1928), and reports on the phenomenon in other species often cite both xenia and metaxenia.
The term "xenia" alone is often applied to embryo/endosperm effects in fruits of species in which pericarp tissue is not economically important, whereas "metaxenia" is applied to fruit in which fleshy carpel and accessory tissues are more economically important. In albuminous seeds, such as corn and other cereal grains, we find "xenia" expressed in endosperm. In exalbuminous seeds, such as pistachio (Pistacia vera L.) and pecan CCarya illinoinensis (Wangenh.) $\mathrm{K}$. Koch], we find "xenia" expressed in embryos. In fleshy fruits, such as date, apple (Malus domestica Borkh.), and persimmon (Diospyros spp.), we find "metaxenia" expressed in the maternal tissues of carpels and accessory tissue. It would seem, then, that how xenia and metaxenia are distinguished depends more on what part of seeds and fruits humans find to be of use than it does on the anatomy and physiology of plants (Tables 2 , 3 , and 4).

\section{THE CASE OF CORN}

As indicated before, much of the early understanding concerning pollen effects on fruits and seeds-as well as some of the confusion in terminology-resulted from early efforts to understand the numerous phenotypic characteristics of corn. There has been considerable progress in corn genetics and physiology since that time, and these advances can shed light on the situation in other species. Xenia and similar expressions in corn have played an invaluable role in these advances by helping determine gene loci and by helping elucidate gene action in this species. In this discussion, only a brief treatment of the points most directly related to the topic of xenia can be attempted. Excellent comprehensive treatments have been edited by Walden (1978) and by Sprague and Dudley (1988).

Let us return to the argument of Swingle (1928) for distinguishing the terms "xenia" and "metaxenia." How well does double fertilization explain xenia in the endosperm? In Swingle's use of this argument, there is an implication derived from Mendelian genetics that embryo and endosperm are somehow genetic equals. Kermicle 1978) suggests that this is not the case. He examines the question of double fertilization and notes that the two products of gene combination, embryo and endosperm, follow rather divergent developmental paths and have two clearly distinct functions in the continuation of the species. Further, the female progenitor of the embryo is a gamete, whereas that of the endosperm is a differentiated cell. It may be an evolutionary advantage for angiosperms that such differentiation between the polar nuclei and the egg cell may afford a particular kind of hybrid vigor not available to the gymnosperms, and this may touch on questions of size in seeds and fruits. Indeed, there are numerous examples of forms in which the embryo sac differentiates more than two polar nuclei, thereby giving rise to an endosperm that has ploidy levels other than $3 \mathrm{~N}$. Kermicle also cites other examples in which ploidy levels differ from the expected $2 \mathrm{~N}$ 
embryo : $3 \mathrm{~N}$ endosperm : $2 \mathrm{~N}$ maternal tissue. Such examples raise questions of gene product dosage as well as other genetic phenomena that may bear on xenic characteristics.

Kermicle (1978) goes on to describe the phenomenon of imprinting, in which there is preferential expression of genes depending on whether the genes were inherited from the paternal or the maternal side. Paternal imprinting may be one explanation for certain cases of xenia. Indeed, paternal imprinting can clearly affect endosperm development and, thereby, kernel size in corn (Lin, 1982). Maternal imprinting, however, may suggest the existence of reverse xenia. Besides imprinting, Kermicle (1978) provides other examples of altered gene potential. One of these is paramutation, which involves variation based on allelic interaction. The other, transposable elements or transposons, has achieved unprecedented topicality because of its importance as a tool in molecular biology (Coe et al., 1988; McClintock, 1950; Walbot and Messing, 1988). Transposons are so-called "jumping genes," which may prevent or alter gene expression by interfering with transcription or with gene regulation. Transposons may be inherited either maternally or paternally, and they are candidates for the root cause of many xenic phenomena. In corn, they are responsible for many of the examples of kernel coloration, especially spotting and mottling of the endosperm, and particularly the aleurone layer. Imprinting, however, also accounts for numerous coloration phenomena in corn. However, both imprinting and transposable elements are associated with a variety of phenotypic expressions other than coloration.

Are there examples of metaxenia in corn? The answer appears to be yes. Transposons may affect embryo and endosperm physiology, and such changes may affect pericarp appearance. However, transposons do not affect pericarp directly by affecting the genome of maternal tissue cells, i.e., transposons do not "jump" from syngamous tissue to maternal tissue. Wright and Neuffer (1989) also describe an example in corn in which the orange color of certain kernels was due to coloration of the pericarp rather than of the aleurone layer or other parts of the endosperm. Also, the coloration was not isolated in chromoplasts or other bodies. Segregation of progeny using this expression, however, suggested that the underlying filial tissue was involved. The effect was due to induced mutation in the pollen used for the cross. Eventually, it was determined that there was a lesion in the embryo's biochemical pathway leading to production of tryptophan and that this led to an accumulation of anthranilic acid, which, as a glycosidal conjugate, was transported to the pericarp, where it became colored. The effects were not limited to the pericarp, however. Inability to produce tryptophan is a lethal trait that leads to seedling death. Endosperm quantity was also reduced. [The involvement of tryptophan in this example provides an intriguing connection to Swingle's hypothesis concern- ing hormonal action in xenic size phenomena since this amino acid is the precursor to indole3-acetic acid (IAA) in plants.]

What, then, are the lessons from corn? One is that double fertilization per se is a rather incomplete explanation for xenia in endosperm. There are numerous complications and complexities to be considered. Another lesson is that xenia in corn exists, but it is not one phenomenon; it is several, involving various genetic and physiological processes. Further, if there is xenia, there may also be "antixenia," as maternal imprinting may be called. Additionally, there are xenic expressions in maternal tissues ("metaxenia"), but these seem inextricably tied to xenic expressions in embryo and endosperm. Perhaps the most important lesson to be learned from corn is that xenia and related phenomena are useful windows on the world of genetics and physiology. Xenia and related phenomena provide a hook by which we can easily grasp the microscopic wonders going on in seeds and fruits.

\section{REDEFINITION}

It may be too late to eliminate the use of the term "metaxenia" to describe pollen effects on fruit parts of purely maternal origin, even though it should now be clear that the term "xenia" was first coined to describe exactly such effects. However, to restore the original term "xenia" to its proper place, it may be necessary to coin a new term-"gamoxenia"-for pollen effects on fruit parts resulting from syngamy, that is, on the embryo and endosperm. "Gamoxenia" is a mirror-image word for "xenogamy," which means outcrossing or hybridization. "Embryoxenia" and "endospermoxenia" could be used to distinguish effects in the two syngamous parts of the seed. Nevertheless, again, it is not clear that xenia and metaxenia (as even Swingle would have it) in date and many other species are distinct phenomena. Only focused research can determine this, and as yet only some xenic color effects and related phenomena in corn have been adequately explained. Later, I will propose specific research in date to begin to address this problem.

But if clear understanding of the phenomena associated with immediate pollen effects must await further scientific research, on the linguistic front there is no reason to wait. From a lexicographical point of view, the definition of xenia should be broadened to include all of the meanings associated with it. As we have seen, xenia was first applied to pollen effects on maternal tissue and was contrasted with hybridization. The term was applied to effects on endosperm when this tissue was thought to be maternal tissue, but the term continued to be used for endosperm even after double fertilization was discovered. Later, xenia was described in embryos as well. If we reexamine the definitions given in Table 1, only that given by Reiger et al. (1976) comprehends all of these points. However, their definition lacks precision and clarity. (Nor should the abstract noun "xenia" be equated to the concrete noun "seeds.") Therefore, on historical, linguis- tic, and scientific grounds, we are compelled to redefine xenia as follows:

The phenomenon of direct differential effects produced by pollen from different sources on the discernible characteristics, especially of size, color, shape, chemical composition, and developmental timing, of parts of seeds and other fruits, including the embryo, endosperm, and maternal tissues, in the period from fertilization until germination.

This limits the use of the term to the effects of syngamy, whether the effects are found in the syngamous tissues themselves or in maternal tissues affected by diffusible or transportable substances-e.g., pigments or hormones and their precursors or conjugated forms-produced by the syngamous tissues. Excluded, then, from this definition are effects on gynoecium tissue resulting from mere pollination. Fertilization is the first required step. Such effects end with the emergence of the radicle, which may be taken as the beginning of the new generation. Thus, differences in time of seed germination traceable to different male parents might be considered xenic effects and added to the list of discernible characteristics. When such effects are limited to the products of syngamy (embryo or endosperm), the term "gamoxenia" may be used. If such effects extend to maternal plant tissue, the term "metaxenia" may be used. Metaxenic effects are, however, probably not limited to the maternal plant tissue but are also found in the embryo and endosperm at the same time. In fact, metaxenic effects probably are never limited exclusively to maternal plant tissues.

Until there is good scientific evidence to maintain a clear distinction between "gamoxenia" and "metaxenia," it would seem prudent to use the term that applies to all immediate effects of pollen in seeds and fruits, and that term is "xenia." The adjective form should be "xenic," a derivation based on Greek models. (The adjective "xenial" should be left to describe relations between human guests and hosts.)

To Focke's two types of xenia, xenochromes (color effects) and xenoplasms (shape effects), we can add xenodoches (size effects), xenochems (chemical effects), and xenochrons (timing effects). To me, distinctions in types of xenia based on the various discernible characteristics make considerably more sense than do distinctions based on syngamous vs. nonsyngamous tissues.

\section{SWINGLE'S HYPOTHESIS REFORMULATED}

Although the above linguistic analysis and solution clarify the meaning of xenia, the biology in most species remains obscure. Swingle (1928) was precocious in suggesting a hormonal cause for xenic size effects in date, but he lacked techniques for testing his hypothesis. His interest seems to have been limited to the effects of diffusible auxin, although this name had not yet been suggested for what was later identified as IAA. We 
have new techniques and new understanding, so we may reformulate Swingle's hypothesis and actually test it. The hypothesis can be stated in this way:

In date, differential xenic size effects can be ascribed to different concentrations in one or several of the three hormones most closely associated with fruit growth: auxin, cytokinins, and/ or gibberellic acid. Smaller fruits (seed + pericarp) will have lower levels of the hormone(s); larger fruits will have higher levels of the hormone(s). Addition of exogenous hormone(s) will increase size in both large and small fruits.

Analysis could be carried out on extracts of fruit taken at several times, beginning with pollination and ending just before sclerification of the seed coats. Pollination methods and materials used should be those given by Nixon (1928a,1928b). Separate groups of flowers might be pollinated with two pollens known to produce xenic effects, others would have hormones applied to these same crosses, and yet other flowers would be bagged and left unpollinated to develop parthenocarpically. Modern techniques for hormone analysis make testing of this hypothesis eminently possible.

\section{FURTHER RESEARCH}

The experiment suggested is but a tenuous first step in trying to understand xenic size effects in date and the phenomenon as a whole. The assays to be used might highlight one hormone in particular whose workings can be studied further. The role of the hormone in quantitative xenia in date can be verified using substances that block hormone action, synthesis, or transport. Yet other important questions will remain. Is the hormone produced by the embryo alone, the endosperm alone, or by both acting in concert? More exacting studies requiring microscopic dissection of the fruit would have to follow. Are the different hormone levels reflective of additive genetic effects? Or are transposable genetic elements that deactivate hormone-producing genes in the small fruit perhaps responsible? How can such work help identify gene loci and biochemical pathways in this species? Indeed, there will be much left to investigate. For example, determination of the physiological and genetic bases for color and shape changes in date and other species might necessitate other experimental approaches, perhaps along the lines already used in corn. The suggested investigation of xenic size effects in date is limited in scope and goals. Such work could, nevertheless, help rekindle interest in a long-neglected area of plant research. What is certain is that xenia and related phenomena can provide a window to a greater understanding of plant physiology and genetics, and this new view can lead to new methods for breeding and for culture and production of horticultural and other crops. Description must now give way to explanation and exploitation.
Literature Cited

Blaringhem, M.L. 1919. Note sur la xénie chez le chatâigner. Bul. Soc. Bot. France 66:354356.

Bradley, M.V. and J.C. Crane. 1975. Abnormalities in seed development in Pistacia vera L. J. Amer. Soc. Hort. Sci. 100:461-464.

Burton, G.W., R. Rabson, and H. Axmann. 1980 Immediate effect of male and female gametes and $\mathrm{N}$ on five pearl millet grain characteristics. Crop Sci. 20:7-9.

Church. R.M. and R.R. Williams. 1983. Comparison of the compatibility and metaxenia effects of several dessert apple and ornamental Malus cultivars with Cox's Orange Pippin. J. Hort. Sci. 58:343-347.

Coe, E.H., Jr., M.G. Neuffer, and D.A. Hoisington. 1988. The genetics of corn. p. 81-258. In: G.F. Sprague and J.W. Dudley (eds.). Corn and corn improvement. 3rd ed. Amer. Soc. Agron., Crop Sci. Soc. Amer. and Soil Sci. Soc. Amer., Madison, Wis.

Correns, C. 1899. Untersuchungen über die Xenien bei Zea mays. Berichte der Deutschen Bot. Gesellschaft 17:410-417.

Correns, C. 1901. Bastarde Zwischen Maisrassen, mit bersondere Berücksichtung der Xenien. Bibliotheca Botanica, 53.

Crane, J.C. and B.T. Iwakiri. 1980. Xenia and metaxenia in pistachio. HortScience 15:184-185.

Darwin, C. 1896. The variation of animals and plants under domestication, vol. 1. D. Appleton, New York. p. 360-361, 427-435.

deVries, H. 1899. Sur la fécondation hybride de l'albumen. Comptes rendus de l'Académie des Sciences (Paris) 129:973-975.

Farooqi, A.A. and M.M. Rao. 1976. Studies on metaxenia in sapota (Achras sapota L.) Mysore J. Agr. Sci. 10:413-423.

Focke, W.O. 1881. Die Pflanzen-Mischlinge: ein Beitrag zur Biologie der Gewächse. Bomtraeger, Berlin. p. 510-518.

Freytag, G.F. 1979. Metaxenia effects on pod size development in the common bean. J. Hered. 70:444-446.

Griggs, W.H., H.T. Hartmann, M.V. Bradley, B.T. Iwakiri, and J.E. Whisler. 1975. Olive pollination in California. Calif. Agr. Expt. Sta. Bul. 869.

Harrison, G.T. 1931. Metaxenia in cotton. J. Agr. Res. 42:521-544.

Hellmann, E.W. and J.N. Moore. 1983. Effect of genetic relationship to pollinizer on fruit, seed, and seedling parameters in highbush and rabbiteye blueberries. J. Amer. Soc. Hort. Sci. 108:401-405.

Hussein, F., S. Moustafa, and I. Mahmoud. 1979. The direct effect of pollen (metaxenia) on fruit characteristics of dates grown in Saudi Arabia. Proc. 3rd Conf. Biol. Aspects, Saudi Arabia. p. $69-78$

Kellerman, W.A. and W.T. Swingle. 1888. Experiments in cross-fertilization of corn. Annu. Rpt. Kansas Expt. Sta. 1:316.

Kermicle, J.L. 1978. Imprinting of gene action on maize endosperm. D. 357-371. In: D.B. Walden (ed.). Maize breeding and genetics. Wiley, New York.

Khalifa, A., S. Azzouz, M. Yousef, Z.M. Hamdi, and H. El-Masry. 1980. Effect of source of pollen on the physical and chemical quality of 'Ahmat' date variety. Agr. Res. Rev. (Egypt) 58:1523.

Kirkpatrick, E.M. (ed.). 1987. Chambers 20th Century dictionary. New ed. Chambers, Edinburgh.

Kovacs, S. 1976. Results of experiments on metaxenia in apple (in Hungarian; English abstract). Kerteszeti Egyetem Kozlemenyei 40:155163.
Krumbholz, G. 1932. Untersuchungen über das Vorkommen von Xenien und Metaxenien bei Apfeln. Gartenbauwissenschaft 6:404-424.

Lin, B.-Y. 1982. Association of endosperm reduction with parental imprinting in maize. Genetics 100:475-486.

Mackowiak, M. 1974. The effect of alien pollen on the variability of fruit properties in the apple variety Wealthy (in Polish; English abstract). Pozn. Towarz. Pryz. Nauk 37:183-192.

Marquard, R.D. 1988. Outcrossing rates in pecan and the potential for increased yields. J. Amer. Soc. Hort. Sci. 113:84-88.

McClintock, B. 1950. The origin and behavior of mutable loci in maize. Proc. Natl. Acad. Sci. USA 36:344-355.

McKay, J.W. and H.L. Crane. 1938. The immediate effect of pollen on the fruit of the chestnut. Proc. Amer. Soc. Hort. Sci. 36:293-298.

Morris, W. (ed.). 1976. The American Heritage dictionary of the English language. Houghton Mifflin, Boston.

Nawaschin, S. 1898. Resultate einer Revision des Befruchtungsvorgänger bei Lilliun martagon und Fritillaria tenella. Bul. de l'Académie Imp. de St. Petersbourg. 9:1-6.

Nebel, B.R. 1931. Xenia and metaxenia in apples. Tech. Bul. 170. New York State Agr. Expt Sta., Geneva.

Nebel, B.R. 1932. Xenia and metaxenia in apples. Proc. Natl. Acad. Sci. USA 18:356-360.

Nebel. B.R. 1936. Metaxenia in apple. J. Hered. 27:345-349.

Nebel, B.R. and Z.I. Kertesz. 1934. Metaxenia and xenia in apples. Gartenbauwissenschaft 9:4564.

Neufeldt, V. (ed.). 1988. Webster's New World dictionary of American English. 3rd College ed. Webster's New World, New York.

Ninan, C.A., AS. Pankajakshan, and V. Rudhakishnan. 1936. Preliminary observations on the influence of pollen parent in copra content in coconut (Cocos nucifera L.). Ind. Coconut J. 16:174-178.

Nixon, R.W. 1928a. The direct effect of pollen on the fruit of the date palm. J. Agr. Res. 36:97128

Nixon, R.W. 1928b. Immediate influence of pollen in determining the size and time of ripening of the fruit of the date palm. J. Hered. 19:240254.

Nixon, R.W. 1931. The commercial utilization of differences in time of ripening of dates due to pollen. Date Growers' Inst. Rpt. 8:5-6.

Nixon, R.W. 1934. Recent pollination experiments. Date Growers' Inst. Rpt. 11:9-11.

Nixon, R.W. 1935. Metaxenia in dates. Proc. Amer. Soc. Hort. Sci. 32:221-226.

Nixon, R.W. 1936. Metaxenia and interspecific pollinations in Phoenix. Proc. Amer. Soc. Hort. Sci. 33:21-26.

Nixon. R.W. 1956. Effect of metaxenia and fruit thinning on size and checking of Deglet Noor dates. Proc. Amer. Soc. Hort. Sci. 67:258-264.

Noguchi, Y. 1934. Metaxenia in the Japanese persimmon. Jpn. J. Bot. 7:61-71.

Nyeki, J. 1972. Metaxenia studies of pear varieties (in Hungarian; English abstract). Acta Agron. Acad. Sci. Hungaricae 21:75-80.

Osman, A.M.A., W. Reuther, and L.C. Erickson. 1974. Xenia and metaxenia studies in the date palm Phoenix dactylifera L. Date Growers' Inst. Rpt. 51:6-16.

Pausheva, Z.P. and T.V. Dontsova. 1981. Protein component composition in the achenes of buckwheat varieties and species and its inheritance following hybridization (in Russian; English abstract). Sel'skokhozyaistvennaya Biologiya 16:416-422.

Peebles, R.H. and C. Hope. 1937. The influence 
of different pollens on the development of the pistachio nut. Proc. Amer. Soc. Hort. Sci. 34:2932.

Pontikis, K.A. 1977. Contribution to studies on the effect of pollen of different species and cultivars of the genus Pistacia on nut development and quality (in Greek; English abstract). Anotate Geoponike Shole Athhenon, 1975.

Purohit, A.G. 1987. Effect of pollen parent on seed hardness in pomegranate. Ind. J. Agr. Sci. 57:753-755.

Ream, C.L. 1976. Metaxenia effect of pollen from inbred male palms on ripening period and size of date fruit. Date Growers' Inst. Rpt. 53:2122.

Reiger, R., A. Michaelis, and M.M. Green (eds.). 1976. Glossary of genetics and cytogenetics, classical and molecular. 4th ed. Springer-Verlag, Berlin.

Rejman, A. 1983. The influence of pollinators on fruit set and some characters of Close apples. Acta Hort. 139:29-31.

Schaffner, J.H. 1928. Ectogony or metaxenia? Science 68: 274.

Sedgley, M. and A.R. Griffin. 1989. Sexual reproduction of tree crops. Academic, London. p. $165-167$.

Shafaat, M. and H.R. Shabana. 1980. Metaxenic effect in date palm fruit. Beitr. Trop. Landwirtsch. Veterinärmed. 18:117-123.
Sharma, S.D., S.N. Tripathi, H.S. Dhuria, and J.S. Chauhan. 1977. Note on the effect of pollen parent on physico-chemical properties of some peach varieties. Ind. J. Agr. Sci. 47: 632634.

Soule, J. 1985. Glossary for horticultural crops. Wiley, New York.

Sprague, G.F. and J.W. Dudley (eds.). 1988. Corn and corn improvement. 3rd ed. Amer. Soc. Agron., Crop Sci. Soc. Amer., and Soil Sci. Soc. Amer., Madison, Wis.

Stancevic, A.S. 1971. Metaxenia in the sweet cherry. The effect of pollen of the paternal variety on the time of ripening of some varieties of sweet cherry (in Croatian; English abstract). Jugoslovensko Vocarstvo 15:11-17.

Strasburger, E. 1878. Uber Polyembryonie. Zeitschr. für Naturwiss. 12:654-678.

Swingle, W.T. 1928. Metaxenia in the date palm, possibly a hormone action by the embryo or endosperm. J. Hered. 19:257-268.

Thone, F. 1926. Plant physiology at the Ithaca Congress. Plant Physiol. 1:292-305.

Tufts, W.P. and C.T. Hansen. 1933. Xenia and metaxenia in the Bartlett pear. Proc. Amer. Soc. Hort. Sci. 30:134-139.

Vagvolgyi, S. and I. Gaal. 1987. Untersuchungen zum Auftreten von Metaxenien bei der Sonnenblume (H. annuus L.). Angewandte Botanik 61:305-308.
Vartapetyan, V.V. and T.V. Kocheskova. 1981. The phenomenon of metaxenia in apple (in Russian; English abstract). Sel'skokhozyaistvennaya Biologiya 16:754-757.

Walbot, V. and J. Messing. 1988. Molecular genetics of corn. p. 389-430. In: G.F. Sprague and J.W. Dudley (eds.). Corn and corn improvement. 3rd ed. Amer. Soc. Agron., Crop Sci. Soc. Amer., and Soil Sci. Soc. Amer., Madison, Wis.

Walden, D.B. (ed.). 1978. Maize breeding and genetics. Wiley, New York

Westwood, M.N. 1989. Temperate-zone pomology. W.H. Freeman, New York. p. 373, 376. Whitehouse, W.E., E.J. Koch, L.E. Jones, J.C. Long, and C.L. Stone. 1964. Influence of pollen from diverse Pisacia species on development of pistachio nuts. Proc. Amer. Soc. Hort. Sci. 84:224-229.

Winburne, J.N. (ed.). 1962. A dictionary of agricultural and allied terminology. Michigan State Univ. Press, East Lansing, Mich.

Wright, A.D. and M.G. Neuffer. 1989. Orange pericarp in maize: filial expression in a maternal tissue. J. Hered 80:229-233.

Zedelbauer, E. 1926. Apfelxenien. Fortschritte der Landswirtschaft 1:8-9.

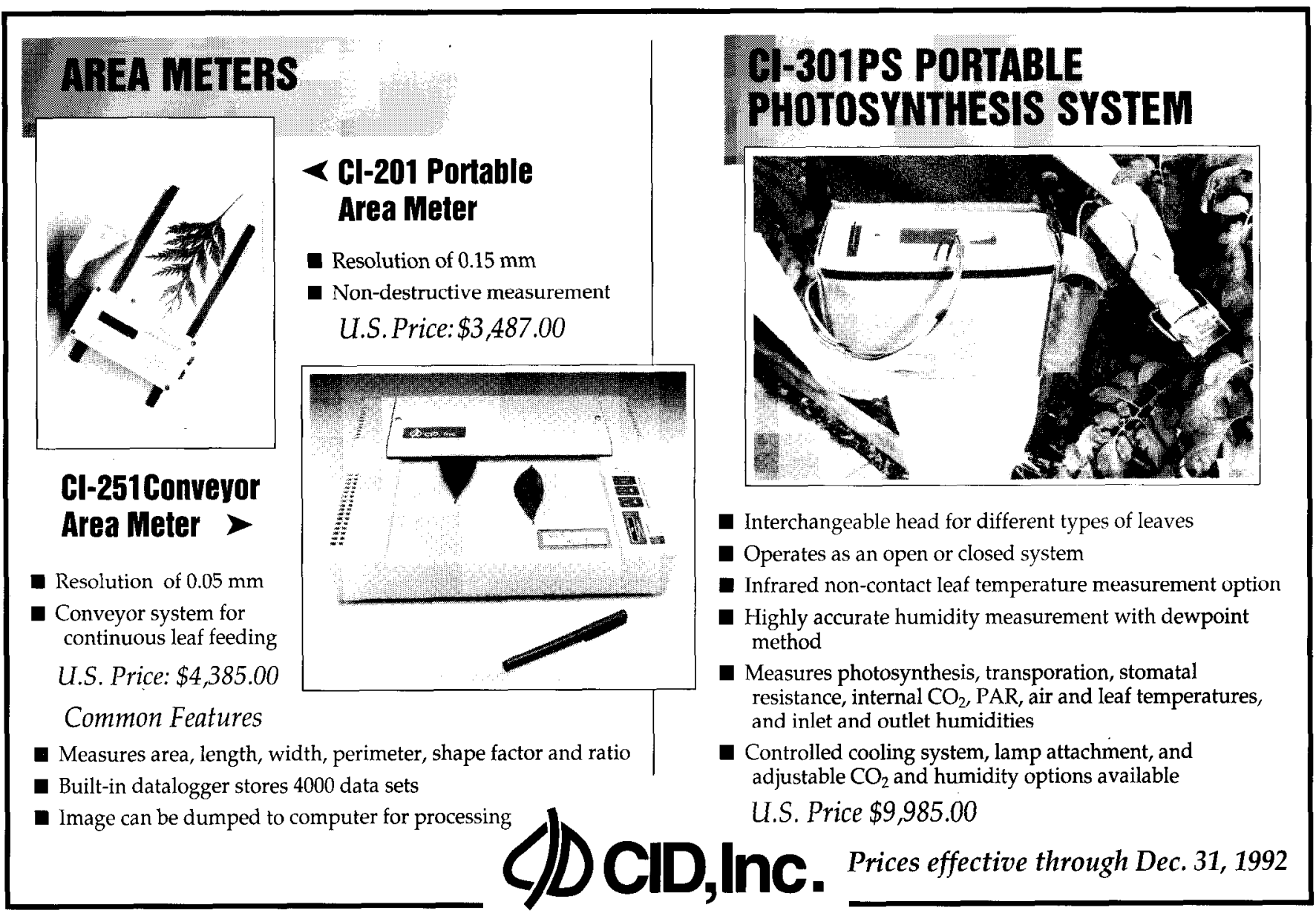

P.0. Box 9008 - Moscow, ID 83843 U.S.A. - Phone (800) 767-0119 FAX (208) 882-9461 - TeleX: 414100CID INC UD 